Paper presented at The Second International Theorising Education Conference: The Future of Theory in Education: Traditions, Trends, Trajectories, Stirling, 7 - 9 June 2012

\title{
LeARNing AS CALling AND RESPONDING
}

\section{Lotta Jons, Stockholm University, Sweden}

In 2008, I theorized the teacher-student-relation as a matter of the teacher paying heed to, responding responsibly to, and calling her student. The theorizing was undertaken by utilizing a philosophical methodology suggested by Gilles Deleuze and Félix Guattari (1994), and resulted in a conceptual framework conveying pedagogical relations as a matter of Calling and Responding.

In the present paper, I intend to take this theorization one step further by investigating the effects of theorizing another pedagogical relation by means of the concept Calling and Responding. The relationship I have in mind is the one between the student and the subject she is studying. This paper thus explores the phenomenon of learning, regarded as an existential dialogue between the student and the subject. The investigation performed here will be described in two steps. First, there is an outlining categorization of the theoreticalphilosophical underpinnings of the framework of Calling and Responding, as it pertains to the phenomenon of learning. This is followed by an exploration of how these underpinnings affect the notion of learning, i.e. an investigation of learning perceived as a question of Calling and Responding.

\section{An existential and relational notion of learning}

Learning is a phenomenon that has been - and still is - conceived of in many different ways. Back in the 1960s, the behaviourist paradigm conditioned my own schooling, and we are all acquainted with cognitive, constructivist and social theories of learning, to mention but a few. There is now a growing interest in existential dimensions of learning as well as in applying a relational perspective on pedagogical undertakings, noticeable in publications by scholars such as Göran Björk (2000), Gert Biesta 1999; 2004a; 2004), Silwa Claesson (2011), Geir Karlsen (2003; 2004), and Sharon Todd (2001; 2003a; 2003b). In the present paper, I put forth learning as an existential dialogue, affording yet another approach to how we might perceive, understand, and talk about, learning.

Discerning the interpreting relation between the student and her subject within the conceptual framework of Calling and Responding, implies understanding learning as a process of paying heed, responding responsibly, and calling. Together, the phases of that process constitute an existential dialogue of summons and responsible responses accommodating to these summons. The first phase of the process, the paying heed to the world summoning you, is a receptive - still not passive - phase. This is a phase requiring you to "be at disposal and openly receive", as Buber (1993a, p. 39) puts it. The second phase is a reactive one, and is simultaneously expressed as a response and a responsibility. The third and last phase is an active one, aiming at summoning the world, meaning in the case of learning, e.g. a subject or an assignment. Thus, in applying the framework of Calling and Responding to the notion of learning, I suggest in this paper that learning may be delineated as a matter of learner and subject summoning and responding responsibly to one another, thereby also suggesting that learning is a phenomenon with a radical impact on the being of the student as well as of the subject, as I will clarify below. 
Paper presented at The Second International Theorising Education Conference: The Future of Theory in Education: Traditions, Trends, Trajectories, Stirling, 7 - 9 June 2012

\section{Theoretical underpinnings of the Calling-and-Responding-framework as it pertains to learning}

I don't believe it is too precipitate to state that most views of learning could be said to presuppose interpretation, or, to put it the other way around, that interpretation could be said to account for a substantial part of learning, regardless of from what perspective one thinks of learning. In order to facilitate the categorization of the theoretical underpinnings, pertaining to the idea of learning as a situation of Calling and Responding, I therefore find it fit to confine this procedure to analysing the underpinnings of different perspectives on interpretation. The present investigation is meant to work as a backdrop, against which learning as a matter of calling and responding might be understood, and the intention is to clarify the consequence this normative and existential dialogical notion of interpretation may have on how learning is understood.

With the intention to elaborate on a notion of interpretation derived from Martin Buber's philosophy of dialogue (see Buber 1961; 1967; 1990; 1993a; 1993b; 1993c; 1994; 1995; 1996), I set out by differentiating between epistemological, ontological, communicative, and axiological practices of considering the phenomenon of interpretation. Elaborating on interpretation from these different perspectives, I think of them as alternate perspectives when conceiving for example the world, man's being, or understanding. This means that I use them to view aspects essential to the understanding of interpretation - such as being, knowing, and truth - trough different lenses. By alternating between these different lenses, I mean to put forward four different inklings of interpretation - namely, one epistemological, one ontological, one communicative, and one axiological - while simultaneously clarifying the outlook on being, knowing, and truth, pertaining to each and one of them.

Through the epistemological lens: being, knowing, truth, and hence, interpreting

Understood within the epistemological paradigm, being is well known - and may be said to have been taken for granted - as a presence (see e.g. Heidegger 1993; 1998; Vattimo 1996). To know is consequently comprehended as a presence grasping another presence, be it a thing or a phenomenon, and truth, i.e. the result of the grasping act, is established accordingly, either through correspondence to reality per se, or through coherence with other truths.

This leads us to the notion of interpretation, which within the epistemological paradigm is conceived of as a matter of apprehending a presence in its correspondence or coherence with other presences, an enterprise recognizable, as I see it, from e.g. Friedrich Schleiermacher's and Wilhelm Dilthey's hermeneutical theories (se e.g. Gadamer 2000; Kepnes 1992; Vattimo 1996). It is pivotal to emphasize that this epistemological idea of interpretation is not incorporated in the theoretical underpinnings of the concept of Calling and Responding, but rather is employed here to take a stance against.

In contrast, the ontological and the communicative perceptions of being, knowing, truth, and the consequential interpretation, are incorporated and even transcended in the theoretical underpinnings of the concept Calling and Responding. By outlining how being, knowing, truth, and interpretation are conceived ontologically and communicatively, I intend to clarify how the axiological notion of these aspects of life incorporates and transcends them.

Ontological: being, knowing, truth, and therefore, interpreting

Within the ontological paradigm, being has been carefully considered and delineated, for example by Martin Heidegger (1992; 1993), as a matter of being-in-the-world, a perception elaborated by Jean-Luc Nancy (2000) as coming-into-presence. 
Paper presented at The Second International Theorising Education Conference: The Future of Theory in Education: Traditions, Trends, Trajectories, Stirling, 7 - 9 June 2012

Denoting quite a different view of being, the shunning of the epistemological perspective might proceed also in a different idea of knowing. Actually, the idiom "knowing" does not quite lend itself to adequately be denoting ontological, communicative, and axiological perceptions of what it means to relate oneself to the surrounding phenomena of the world. However, following Rorty's (1980) suggestion not to think of hermeneutics as another way of knowing, but rather as another way of coping with the world, makes it possible, I think, to employ a more adequate vocabulary for speaking of knowing in other terms than epistemological ones. Within the ontological paradigm, coping with the world has been described by Martin Heidegger $(1992 ; 1993)$ as a question of coming to understand one's being-in-the-world, while with Nancy's (2000) understanding of being, we might denote it as a matter of coming to understand how we come-into-presence.

Furthermore, the ontological, communicative, and axiological modes of conceiving truth are quite different. From an ontological point of view, truth is, according to Martin Heidegger (1992; 1993) among others, described as being true, i.e. appearing (or coming-into-presence) in a mode allowing for the realization of one's potentials in line with an authentic manner of being-in-the-world.

Since being-in-the-world is delineated as being linguistically immersed (Gadamer 2000; Heidegger 1992), interpretation accordingly becomes conceived of as a matter of coming to understand and of being able to articulate one's being-in-the-world, or, in Mikhail Bakhtin's wording, as a matter of "authorizing" oneself (see Bakhtin 1981; 1986; 1993; Gadamer 2000; Heidegger 1992; Kepnes 1992; Vattimo 1996; Todorov 1984).

To satisfactory clarify the nature of the axiological paradigm, underpinning the concept of Calling and Responding conveying a different perception of learning here, there is a need for differentiating the ontological linguistic paradigm from what I identify as a purely communicative one. This, I believe, would pave the way for the transition into the axiological paradigm, making it easier to follow.

Communicative: being, knowing, truth, and therefore, interpreting

How might being be conceived within the paradigm denoted here as communicative? As I see it, a communicative notion of being is found in Mikhail Bakhtin's dialogism (see Bakhtin 1993; Todorov 1984.), and might thus be suggested to be conceived of as a matter of responding and addressing the world. "The very being of man..." Bakhtin writes, "... is a profound communication. To be means to communicate." (see Todorov 1984, p. 96 quoting Bakhtin 1984, p. 311-312). Bakhtin hence explains being as an existential dialogue. Holquist's wording for Bakhtin's outlook on being makes it even clearer, as he states that "... we cannot choose not to be - in dialogue, not only with other human beings, but also with the natural and cultural configurations we lump together as "the world". The world addresses us and we are alive and human to the degree that we are answerable, i. e. to the degree that we can respond to addressivity" (Holquist, Michael 2002 p. 30). This manner of conceiving being is also possible to trace in Martin Buber's philosophy of dialogue, as he states that man should be seen not as leading a dialogue, but as being one (1995b, p. 85). Hence, within the communicative paradigm, being should be understood as a dialogue manifested on one hand in man's experiences of things, people, and phenomena addressing her, and on the other hand in the appearances she commits to, manifesting her responses to these utterances.

Consequently, I believe that within the communicative paradigm, an adequate method of conceptualizing the phenomenon of coping with the world would be to think of it in terms of 
Paper presented at The Second International Theorising Education Conference: The Future of Theory in Education: Traditions, Trends, Trajectories, Stirling, 7 - 9 June 2012

responding, since according to Mikhail Bakhtin this is how man copes with utterances addressing her.

How might truth be conceived, when in accordance with this, it is understood as a response to an utterance? Exploring the theoretical grounds of Bakhtin's dialogism, leads me to suggest that truth, when derived from such communicative underpinnings, might adequately be denoted as co-respondence. This implies an utterance that in a true way - or more accurately, truly - responds to the issues and statements put forth in the address.

Interpretation is thus thought of here as a dialogical matter. Regarding interpretation in terms of a dialogue is a tradition with roots in "the linguistic turn", found in Heidegger's, Gadamer's, Kepnes', and Vattimo's hermeneutics as well as in Bakhtin's dialogism (see Bakhtin 1981; 1986; 1993; Gadamer 2000; Heidegger 1992; Kepnes 1992; Vattimo 1996; Todorov 1984). It may be worth noting that in the interpretation of the epistemological paradigm, there is no dialogue, but merely a monologue (see Gadamer 2000; Kepnes 1992; Vattimo 1996).

This brings us to the communicative understanding of interpretation, which is one I like to maintain as being somewhat implicitly known, albeit perhaps not specifically denoted up to now. What I have in mind is a hermeneutic view of reception, outlined within Steven Kepnes' dialogical hermeneutics as well as in Mikhail Bakhtin's dialogism (Bahktin 1981; 1986; 1993; Holquist 2002; Kepnes 1992; Todorov 1984). When exploring this idea of reception, such communicative traits are similarly found within the hermeneutics of Heidegger (1992), Gadamer (2000), and Vattimo (1996). Interpreting becomes in this context a matter of hearing an utterance addressing you and perceiving the issues addressing you therein, capacitating you to in turn respond truly in accordance with the issue conveyed.

Axiological: being, knowing, truth, and therefore, interpreting

Axiology is about the nature of values, and I use the idiom to define the ontological type of normativity found in Martin Buber's philosophy of dialogue. In accordance with the theorization in my thesis (Jons 2008), this is a suitable paradigm for approaching the concept of Calling and Responding, since the buberian notion of dialogicity adds a moral facet (of an ontological type) to the perceptions of being, knowing, truth, and interpretation, in comparison to the ontological and communicative notions. The moral facet being of an ontological type, provides guidance as to whom you want to be(come), and how you consequently choose to respond.

Resting on a view conceiving being as a morally coined existential dialogue, the axiological paradigm recounts the addresses of the world as callings summoning man. Summoning transpires when encountering for instance a person, an assignment, or - when easing into the phenomenon of learning - a subject, and Biesta (2004a p. 79) puts forward responses as a matter of stating "who you are" and "where you stand" morally, i.e. as callings summoning (the phenomena of) the world. Furthermore, being is here to be understood within an essential existentialism, i.e. an essence of potentials being birth-given, relying on man to freely chose and to be responsible for - if and how to realize them.

In the axiological paradigm, to cope with the world means paying heed to its callings, and to the issues therein, summoning you. This strategy of coping with the world incorporates the ontological understanding and articulation of one's being-in-the-world, as well as the communicative perception and response to utterances addressing you. But it also transcends these means of coping with the world by conceiving the utterance as a summons, thereby 
Paper presented at The Second International Theorising Education Conference: The Future of Theory in Education: Traditions, Trends, Trajectories, Stirling, 7 - 9 June 2012

changing the issue of coping with the world into a matter of paying heed to, and responding not only in accordance with the issues lifted therein, but morally as well - in a responsible manner, by acknowledging responsibility for the callings you in turn contribute to the world, and by conceiving the responses as guided by ontological norms of whom to be(come).

Incorporating the ontological and communicative notions of truth, the axiological inkling may be conceived of as a matter of truly co-responding to an address, as a consequence of an utterance that tackles the issues and statements put forth within that addressing comment, in a way that represents your true way of being-in-the-world. As previously mentioned, however, the axiological view of truth transcends the ontological and communicative notions, and does so by adding normativity. This means that man's response is guided not only by the person she strives to be(come), but also by the birth-given potentials she chooses to realize in acknowledgement of the responsibility for the calling. To respond in a true way, or in other words, to cope with the world in a true way, becomes a moral issue of responding in accordance with your beacon and with your potentials, taking responsibility for what you hence actualize and, furthermore, for the manner by which you thereby call on the world.

As stated from the beginning, the suggested axiological view of interpretation, will incorporate and transcend the ontological and communicative views of interpretation, while excluding the epistemological one. Interpretation as an axiological endeavour, should thus be understood as a matter of paying heed to the summoning of the phenomenon calling you, followed by an accommodating response to that summons, by recognizing the potentials possible to identify as responsible to realize, in a calling summoning the world.

What this means, more precisely, when actually interpreting, say a work of art, a text, or maybe - when easing into learning again - information conveyed in a lecture, is that we would not settle for conceiving a dialogue between the interpreter and her object as a matter of interpreting the work of art, or understanding the theory pertaining to a subject, in a fashion that facilitates her articulation of her true being-in-the-world. Neither would we assent to conceiving the interpretive dialogue as a matter of responding in a co-responding way to a text, i.e. addressing its issues and statements by authoring a new text. As I see it, we would do both these things by including these aspects in the interpreting event; but then we would transcend them, by conceiving of e.g. information conveyed in a lecture, as a calling we should pay heed to since it actually summons us to respond to the provided information, and to do so in a manner accommodating to the "whom do I want to be(come)?" as well as to the potentials that I undertake to actualize.

Thus, if learning to a great extent indeed consists of interpretation, how might then learning be understood against this axiological backdrop? In the following paragraph, I will detail the constituted perception of learning in accordance to this axiological paradigm.

\section{Learning as a matter of Calling and Responding}

Contemplating learning within the framework of Calling and Responding, means contemplating learning as an encounter between the learner and the subject. It means thinking of learning as a process of the subject - might it be through a text, a theory, an assignment, etc. - calling the student, summoning her to pay heed to the issue it conveys in order to respond in a responsible way - which means choosing to act in accordance with whom she wants to be(come), and with her moral stance - finally completing the process by calling the subject, i.e. summoning it to pay heed and to respond. Learning is therefore to be understood as a provocative encounter, not only on behalf of the learner but in fact also on behalf of the subject, since it requires dedication and grants an impact on both parties of the existential 
Paper presented at The Second International Theorising Education Conference: The Future of Theory in Education: Traditions, Trends, Trajectories, Stirling, 7 - 9 June 2012

dialogue. The consequence of this provocative encounter is actually that both parties reconstitute their modus operandi of calling and responding to the world, be it by incorporating the encountered (per definition foreign and provocative, or at least new; otherwise it wouldn't accomplish a summons ) or by taking a stance against it. Having done that - incorporated or taken a stance against something new - thus means, having learned. Let us look into the phases of learning more closely when it is conveyed as a process of paying heed, responding responsibly, and calling.

\section{Paying heed}

Comprehended as an existential dialogue, learning begins by the student experiencing being summoned by the subject encountered; that is, the dialogue is initiated, urging the student to pay heed to the predicaments and needs of the subject. The predicaments and needs of a subject concerns for instance the truths it holds, the anomalies it suffers, the theories it relies on, the practice enacted, or the ideologies it holds, and may also concern its content as well as its form. Paying heed is essentially about the learner "being at disposal and openly receiving", as Buber (1993b) formulates it, the subject matter encountered, although - or rather, because - it represents something she either wants to incorporate or to dispute. This is because the encounter conveys something foreign, and (according to Buber 1993b, p109), what is foreign provokes us, either by arousing resonance and desire or by evoking questions, doubts, and aversion. Buber's idea of paying heed is outlined as a matter of conversing in a genuine manner, and serving.

According to Buber (1993b), a genuine dialogue can only take place if the learner and the subject approach each other's true beings, self-contribute unreservedly, and appear as their authentic beings. Hence, in addition to the student approaching the subject's true being, contributing unreservedly to the encounter with her authentic self, there is a need for the teacher to present the subject in a way that enables also the subject to approach the learner's true being, while contributing unreservedly to the encounter by its authenticity.

Having stated those requirements, however, it needs to be pointed out that a genuine conversation neither can be planned nor controlled. It arises within the relation, denoting that it is constituted in the line of conversation between the student and the subject and is therefore unpredictable; and in order for it to materialize, enabling it is a precondition, hence a task for the teacher.

Serving is a matter of recognizing and supporting potentials still dormant within the participants of the encounter. This means that in order to consider the dialogue genuine, a mutual serving is required. Even though the student may be recognizing and supporting potentials yet dormant within the subject, when undertaking this serving, it is crucial that she acknowledges the subject's own "destiny", i.e. its assignment in being. As a consequence, she is in a really true sense supporting the subject "deciding its self" (in Buber's words), which she achieves foremost by refraining from imposing her own procedure of Calling and Responding the world, on to the subject. According to this axiological way of conceiving the parties involved in learning, each subject is regarded as holding and fulfilling a unique assignment in the being event, concordant with each subject's inkling of calling and responding to the world. Serving, thus, is about the learner nurturing the substance of a subject in a way fitting the subject's process of deciding its self. In fact, according to this buberian perspective, the learner is obliged to influence the beings of the subjects encountered in the line of education, while not interfering with them, thereby enabling each subject to "decide" its self in order to grant their particular contribution to the whole of being. 
Paper presented at The Second International Theorising Education Conference: The Future of Theory in Education: Traditions, Trends, Trajectories, Stirling, 7 - 9 June 2012

This phase of the learning dialogue is also a matter of the subject serving the learner, meaning that the subject recognizes and supports the learner's birth-given potentials. The question is: how might this be perceived? I believe this is the right moment to bring the teacher into the situation. In my opinion, it is by what we otherwise characterize as "individualizing" our teaching and teaching-learning-assignments that the learners' potentials may be recognized and supported.

Thus, the first phase of the learning dialogue is when the learner and the subject pays heed to one another's predicaments and needs by having a genuine dialogue, thereby serving each other in the process of each part deciding its self.

\section{Responding responsibly}

The second phase of the learning dialogue is about the learner responding in a responsible manner to the summoning of the subject. The learner responds exactly to the very predicaments and needs of the subject that awakens her desire, curiosity, or aversion, and does so by actualizing those very unique, yet up to now dormant, subject related potentials of hers, thereby establishing herself as a contributor to the subject's way of calling and responding to the world.

But that is not all. Responding responsibly also requires of the learner to acknowledge a personal responsibility for the procedure by which she calls and responds to the world through the subject, or, in other words, for how she comes to represent the subject. Thus, when responding in a responsible manner to the subject's summons, the learner states not only "who she is", but also "where she stands" morally, and she does so through her visualization of whom she wants to be(come). By this, she is influencing the subject's way of calling and responding.

By responding responsibly, hence, each learner comes to represent the subject in accordance with her unique potentials and norms, consequently realizing different dimensions of the subject's way of calling and responding to the world, hence enlarging the subject itself.

\section{Calling}

The third and concluding phase of the learning dialogue is a matter of the learner calling the subject by way of summons, carrying provocations as well as requirements for responses. Learning is accordingly conceived of as a phenomenon comprising the notion of the learner contributing to the subject deciding its self.

In order to make a true difference to the subject's way of calling and responding to the world, the summoning has to be truly provoking. Therefore, there is a need for the summoning to confront the subject with something foreign, e.g. concerning its content or its form. Truly provoking, the summoning will challenge the truths beheld by the subject, the anomalies it suffers, the theories it relies on, the practice enacted, or the ideologies it holds. Truly provoking, the summoning presents something desired and needed, or something evoking questions, doubts, or aversion, on behalf of the subject. Successfully provoking, the summoning of the learner will awaken dormant potentials within the subject, thereby amplifying its way of calling and responding to the world.

It is with this modus operandi - provided that we indeed conceive of learning in the manner presented here - that the study fields, where we as students and scholars have as our domiciles, will be making progress. 
Paper presented at The Second International Theorising Education Conference: The Future of Theory in Education: Traditions, Trends, Trajectories, Stirling, 7 - 9 June 2012

The calling of the encountered subject requires of the learner to have courage. First to dare being truly affected by the predicaments of and needs for the development characterizing the subject, and then to dare committing herself in a "personal and persuasive manner", a daring accomplished by the learner truly personalizing her summoning of the subject, and acknowledging the responsibility for the way she contributes to its development. Finally, daring to truly impact the subject's way of calling and responding to the world, deciding its self by its own way of calling and responding to the world, indeed requires courage. Within the dialogical framework employed here, this is to be conceived of as the phase completing the process of learning.

\section{Concluding remarks}

By elaborating on learning within the framework of calling and responding, I have proposed learning to be a matter of paying heed to, responding responsibly to, and even calling the subject studied, by way of that, aiming at affording a new modus operandi of conceiving and talking of learning. Applied to the understanding of learning, this framework encourages us to conceive of the matters we present to our students - be it text, speech, questions, answers, theories, examples, or assignments - as callings, summoning them to respond responsibly be it by posing or answering questions, writing papers, or by the way they carry out their assignments in their future vocation - in accordance with "who they are and where they stand". 
Paper presented at The Second International Theorising Education Conference: The Future of Theory in Education: Traditions, Trends, Trajectories, Stirling, 7 - 9 June 2012

\section{References}

Bakhtin, Mikhail M (1981). The dialogic imagination: four essays. (Edited by Michael Holquist). (Translated by Caryl Emerson \& Michael Holquist). Austin: University of Texas press.

Bakhtin, Mikhail M (1986). The Problem of Speech Genres. In Speech Genres and Other Late Essays. (Translated by Vern W Mc Gee). Austin: University of Texas Press.

Bakhtin, Mikhail M (1993). Towards a philosophy of the act. (Translated by Vadim Liapunov, edited by Vadim Liapunov and Michael Holquist). Austin: University of Texas Press. (Russian orig (1986). K filosofii postupka. In Filosofiia i sotsiologiia nauki i tekhniki: Ezhegodnik 1984-1985, pp 82-138. Moscow: Nauka.)

Biesta, Gert (1999). Radical Intersubjectivity. Reflections on a different foundation of education. Studies in Philosophy and Education 18 (4): 203-220.

Biesta, Gert (2004a) Against learning. Reclaiming a language for education in an age of learning. Nordisk Pedagogik (1), 71-82.

Biesta, Gert (2004b). The Community of Those Who Have Nothing in Common: Education and the Language of Responsibility. Interchange 35 (3): 307-324.

Björk, Göran (2000). Pedagogik $i$ exil. En bildningsfilosofisk studie med existentiellt fokus. (Education in exile. A philosophical study of education with an existential focus). ( $\mathrm{PhD}$ dissertation, in swedish with an english summary). Åbo: Åbo Akademi University Press.

Buber, Martin (1961). Two types of faith: a study of the interpenetration of Judaism and Christianity. New York: Harper \& Row.

Buber, Martin (1967). Replies to My Critics. (Translated by Maurice Friedman) In Schlipp, Paul Arthur \& Friedman, Maurice (eds). The Philosophy of Martin Buber. La Salle: Open Court.

Buber, Martin (1990). Människan och hennes bildkonst. (Translated by Pehr Sällström). Ludvika: Dualis. (German orig (1955). Der Mensch und sein Gebild ur Beiträge zu einer philosophischen Anthropologie. Heidelberg: Lambert Schneider.) (English version (1988). Man and His Image-Work. In The Knowledge of Man. A Philosophy of the Interhuman. (Edited by Maurice Friedman, translated by Maurice Friedman and Ronald Gregor Smith).Atlantic Highlands, NJ: Humanities Press.)

Buber, Martin (1993a). Dialogens väsen. Ludvika: Dualis. (German orig (1929/1932). Zwiesprache - Traktat vom dialognischen Leben. Berlin: Schocken-Verlag.) (English version (1965). Dialogue. In Between Man and Man. (Translated by Ronald Gregor Smith). New York: Maximillan Paperbacks.

Buber, Martin (1993b). Om Uppfostran. (Translated by Lars W Freij). Ludvika: Dualis. (German orig (1953) Reden über Erziehung. Heidelberg: Verlag Lambert Schneider.) (English version (1965). Education. In Between Man and Man. (Translated by Ronald Gregor Smith). New York: Maximillan Paperbacks. 
Paper presented at The Second International Theorising Education Conference: The Future of Theory in Education: Traditions, Trends, Trajectories, Stirling, 7 - 9 June 2012

Buber, Martin (1993c). Människans väg. (Translated by Monica Engström). Ludvika: Dualis. (German orig (1960). Der Weg des Menschen nach der chassidischen Lehre. Heidelberg: Verlag Lambert Schneider.) (English version (1965). The Way of Man. According to the Teachings of Hasidism. London: Collins Books.

Buber, Martin (1994). Jag och Du. (Translated by Margit and Curt Norell) Ludvika: Dualis. (German orig (1923). Ich und Du. Heidelberg: Lambert Schneider.) (English version (1970). I and Thou. (2nd ed). Translated by W Kauffman). New York: Charles Scribner's Sons.

Buber, Martin (1995a). Det mellanmänskliga. (2nd ed). (Translated by Pehr Sällström). Ludvika: Dualis. (German orig (1954). Elemente des Zwischenmenschlischen. In Die Schriften über das dialogische Princip. Heidelberg: Verlag Lambert Scneider.) (English version (1988). Elements of the Interhuman. In The Knowledge of Man. A Philosophy of the Interhuman. (Edited by Maurice Friedman, translated by Maurice Friedman and Ronald Gregor Smith).Atlantic Highlands, NJ: Humanities Press.)

Buber, Martin (1995b). Logos. Två essäer. Ludvika: Dualis. (Germ orig (1962). Logos - zwei Reden. Heidelberg: Verlag Lambert Schneider.) (English version (1988). The Word that is Spoken and What is Common to All. In The Knowledge of Man. A Philosophy of the Interhuman. (Edited by Maurice Friedman, translated by Maurice Friedman and Ronald Gregor Smith).Atlantic Highlands, NJ: Humanities Press.)

Buber, Martin (1996). Distans och relation. Bidrag till en filosofisk antropologi. (Translated by Pehr Sällström). Ludvika: Dualis. (Germ orig (1951). Urdistanz und Beziehung. Heidelberg: Verlag Lambert Schneider.) (English version (1988). Distance and Relation. In The Knowledge of Man. A Philosophy of the Interhuman. (Edited by Maurice Friedman, translated by Maurice Friedman and Ronald Gregor Smith).Atlantic Highlands, NJ: Humanities Press.)

Claesson, Silwa (red) (2011). Undervisning och existens. (Teaching and Existence). (In swedish). Gothenburg: Daidalos.

Deleuze, Gilles \& Guattari, Félix (1994). What is Philosophy? (Translated by Hugh Tomlinson and Graham Burchill). London: Verso. (French orig (1991). Qu'est-ce que la philosophie? Paris: Éditions de Minuit.)

Gadamer, Hans-Georg (2000). Truth and method. (2nd rev ed). (Translated and revised by Joel Weinsheimer and Donald G Marshall). New York: Continuum. (Germ orig (1986). Gesammelte Werke. Vol 1. (5th revised and expanded ed). Tübingen: J C B Mohr.

Heidegger, Martin (1998). Metafysiken som varats historia. (Translated by Daniel Birnbaum \& Sven-Olov Wallenstein). Stockholm: Thales. (German orig (1961). Die Methaphysik als Geschichte des Seins. Stuttgart: Verlag Günter Neske.)

Heidegger, Martin (1992). Varat och Tiden del I \& II. (Translated by Richard Matz). Gothenburg: Daidalos. (German orig (1926). Sein und Zeit. Tübingen: Max Niemeyer Verlag.) (English version (1978). Being and Time. (Translated by John Macquarrie and Edward Robinson). Oxford: Basil Blackwell).

Heidegger, Martin (1993). Letter on humanism. (Translated by Frank Capuzzi with J Glenn Gray). In Farrell, David (ed). Heidegger. The basic writings. San Francisco: Harper. (German orig (1947). Brief über den Humanismus. Bern: A Francke Verlag.) 
Paper presented at The Second International Theorising Education Conference: The Future of Theory in Education: Traditions, Trends, Trajectories, Stirling, 7 - 9 June 2012

Holquist, Michael (2002). Dialogism. Bakhtin and his world. (2nd ed). London: Routledge.

Jons, Lotta (2008). Till-tal och an-svar. En konstruktion av pedagogisk hållning. (Calling and Respons(e)ibility. A Construction of Pedagogical Creed. (PhD Dissertation, in Swedish with an English summary). Stockholm: Stockholm University, Department of Education.)

Karlsen, Geir (2003). Mфtets etikk og estetikk. Betraktninger om et alternativt laererideal. (The ethics and aesthetics of encountering. Reflections on an alternate teacher-ideal. $(\mathrm{PhD}$ dissertation, in Norwegian).Trondheim: Pedagogiska institutet vid NTNU.

Karlsen, Geir (2004). The Potential of Vulnerability. Challenges in personal teaching. Paper presented at Philosophy of Education Society of Great Britain Conference at University of London, Institute of Education. Internet: http://k1.ioe.ac.uk/pesgb/z/Karlsen.pdf on 2007-1219.

Kepnes, Steven (1992). The Text as Thou. Martin Bubers Dialogical Hermeneutics and Narrative Theology. Indianapolis: Indiana University Press.

Nancy, Jean-Luc (2000). Being Singular Plural. (Translated by Robert D Richardson and Anne E O’Byrne). California: Stanford University Press. (French orig (1996). Etre singulier pluriel. Paris: Èditions Galilée.)

Rorty, Richard (1980). Philosophy and the Mirror of Nature. Oxford: Blackwell

Todd, Sharon (2001). "Bringing more than I contain": ethics, curriculum and the pedagogical demand for altered egos. Journal of Curriculum Studies 33 (4): 431-450.

Todd, Sharon (2003a). A fine risk to be run? The Ambiguity of Eros and Teacher Responsibility. Studies in Philosophy and Education 22 (1): 31-44.

Todd, Sharon (2003b). Learning from the Other. Levinas, Psychoanalysis, and Ethical Possibilities in Education. Albany: State University of New York Press.

Todorov, Tzvetan (1984). Mikhail Bakhtin: The Dialogical Principle. (Translated by Wlad Godzich). Manchester: Manchester University Press.

Vattimo, Gianni (1996). Utöver tolkningen. Hermeneutikens betydelse. (Translated by William Fovet). Gothenburg: Daidalos. (English version (1997). Beyond interpretation: the meaning of hermeneutics for philosophy. (Translated by David Webb). Cambridge: Polity Press.) 